\title{
VERTICAL CAPACITY OF BUCKET FOUNDATIONS IN UNDRAINED SOIL
}

\author{
Amin BARARI, Lars Bo IBSEN \\ Department of Civil Engineering, Aalborg University, Sohngårdsholmsvej 57, \\ 9000 Aalborg, Denmark
}

Received 27 Feb 2012; accepted 07 May 2012

\begin{abstract}
Offshore wind turbine structures are traditionally founded on gravity concrete foundations or mono-piles. Bucket foundations were developed for the offshore oil and gas industry and are now being used in wind turbine construction. The loading in this application is characterized by a vertical load due to the slender construction combined with horizontal forces inducing a large overturning moment. Field tests on bucket foundations were performed to gain insight into the vertical load response of bucket foundations in clay soils. The field tests were accompanied by finite element numerical simulations in order to provide a better understanding of the parameters influencing bucket foundation behaviour.
\end{abstract}

Keywords: bucket foundation, vertical loading, bearing capacity, Mohr-Coulomb model, finite element.

Reference to this paper should be made as follows: Barari, A.; Ibsen, L. B. 2014. Vertical capacity of bucket foundations in undrained soil, Journal of Civil Engineering and Management 20(3): 360-371.

http://dx.doi.org/10.3846/13923730.2013.801915

\section{Introduction}

Increasing attention has recently been focused on the development of environmentally safer means of energy production. Wind turbines represent one of the most efficient energy production technologies and their use has rapidly expanded due to environmental considerations. Many projects have recently been initiated to expand wind energy production across the world. It is common practice to place wind turbines offshore. A major design issue concerning these offshore structures is the turbine foundation, which can consume up to 30 percent of the total construction cost. Several techniques are available for wind farm foundation construction including gravity foundations (Fig. 1a), bucket foundations (Fig. 1b), monopile foundations (Andersen et al. 2012) (Fig. 1c), and tripod foundations (Fig. 1d). Among the aforementioned foundation types, the bucket foundation system is unique for its convenient installation method and reusability (Ibsen et al. 2004). A bucket foundation is essentially an upside-down bucket-like steel structure which is lowered to the seabed under its own weight and then inserted into the soil by pumping the water from the interior of the bucket. Other advantages of bucket foundations include reduced construction costs and the availability of passive suction forces to counteract uplift.

Recent comprehensive research and development projects have proven that bucket foundations are effective given suitable soil conditions such as fine sand or clay materials in water depths from near-shore to approximately 55 meters (Ibsen et al. 2004; Achmus, Abdel-
Rahman 2005; Abdel-Rahman, Achmus 2005; API 2000; EAU 2004; Feld 2001; Ibsen 2008) .The bucket foundation design reduces the required amount of steel by half compared to traditional monopile solutions, and bucket foundations are much easier to install and do not require heavy installation equipment (Ibsen et al. 2004; Achmus, Abdel-Rahman 2005; Abdel-Rahman, Achmus 2005). The suction installation technology was originally introduced by Shell and is widely used for anchor piles and skirted foundations on offshore structures (Tjelta 1995; Ebrich, Tjelta 1999).

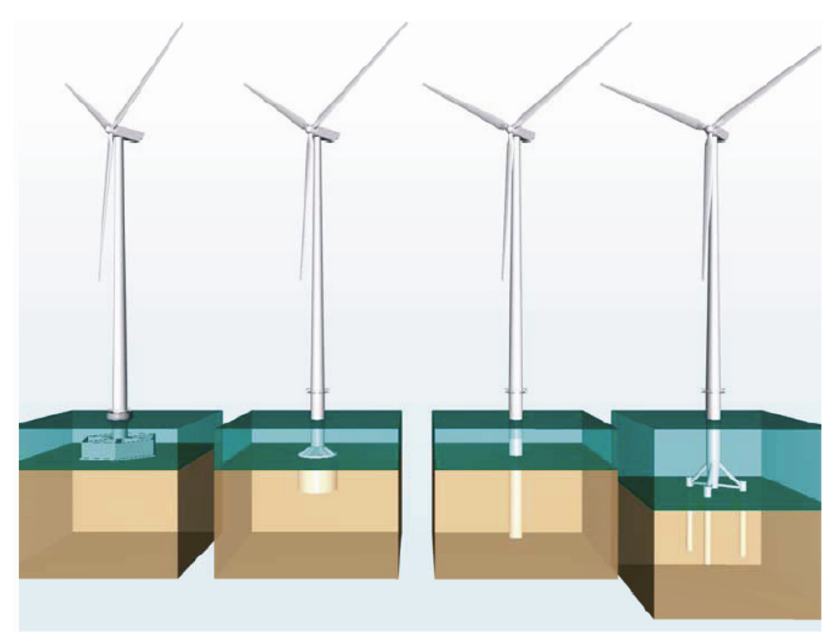

Fig. 1. Offshore foundations employed in wind turbine construction, from left to right: a) gravity foundation; b) bucket foundation; c) monopole foundation; d) tripod foundation 
The choice of foundation type depends on several factors such as soil condition, water depth, structure of the wind turbine, environmental conditions, economics, and politics (Feld 2001). Advantages and disadvantages of the foundation types in relation to the factors presented above are outlined by Liingaard (2006) and Ibsen et al. (2003).

Due to their advantages, bucket foundations have recently attracted the attention of oil and wind turbine companies for additional uses such as gravity platform jackets, jack-ups, offshore wind turbines, subsea systems, and seabed protection structures (API 2000; EAU 2004; Feld 2001, 2006; Ibsen 2008; Senepere, Auvergne 1982; Tjelta 1995; Ebrich, Tjelta 1999; Liingaard 2006; Ibsen et al. 2003; Dyme, Houlsby 1998; Aas, Andersen 1992; Clukey et al. 1995; Allersma et al. 1997, 2000; Houlsby, Byrne 2000; Byrne et al. 2002; Byrne, Houlsby 2004; Andersen, Jostad 1999; Ibsen et al. 2012).

Following extensive research examining the performance of bucket foundations in sand, several models have been developed to describe their behaviour. Feld (2001) investigated the design procedures for bucket foundations within frictional materials by employing combined loading experimental tests as well as non-linear finite element simulations. The tests were performed on a half bucket placed against a transparent wall identifying the net flow during tension and the failure surface at pullout, corresponding to the maximum tensile capacity of the foundation. The buckling of large diameter bucket foundations during installation in sand was analysed by LeBlanc (2009), since the bucket foundation is a thin shell structure and is therefore potentially vulnerable to structural buckling as a result of hydrostatic loading during suction installation. A modified theoretical relationship for bucket foundations analogous to vertical loading of circular foundations in homogeneous and isotropic sand was successfully developed by Ibsen et al. (2012).

Taiebat and Carter (2000) performed finite-element analyses of circular foundations on a homogeneous, purely cohesive soil to investigate the shape of the undrained failure locus for the foundation. The results of the numerical analyses were compared with some of the available theoretical solutions for the undrained bearing capacity of the foundation.

Wang et al. (2006) utilized three-dimensional finite element analysis to model the soil-structure interaction of suction caissons. They modelled the suction caisson and supporting soil as a nonlinear/plasticity problem and presented case studies of several geometries to demonstrate the accuracy of their model.

Ding et al. (2003) estimated soil liquefaction during ice-induced vibration of bucket foundations in the Bohai Sea, China. They analyzed the foundation vibrations using self-excited vibration theory to obtain the maximum ice-induced dynamic shear stresses in the soil.

Zhang et al. (2007) performed a series of centrifuge model tests to investigate the behaviour of suction bucket foundations to be used on a tension leg platform in the Bohai Sea. Lateral loadings were included to study the characteristics of structural vibration-induced soil lique- faction. They constructed a centrifuge model comprising two layers of soil: a $210 \mathrm{~mm}$-thick silt layer at the top and a $20 \mathrm{~mm}$-thick coarse sand layer at the bottom with the water level approximately $20 \mathrm{~mm}$ above the soil surface. Excess pore water pressures reached a maximum at depths of $1-1.5 \mathrm{~m}$.

Zhang et al. (2004) presented a finite element simulation of the seepage field generated by suction penetration of a bucket foundation into the sea floor. The water head and its gradient on both sides of the bucket foundation skirt were computed in order to calculate the changes in penetration resistance with penetration depth.

Although some researchers have investigated the behaviour and bearing capacity of bucket foundations in clay (Ibsen et al. 2004; Achmus, Abdel-Rahman 2005; Abdel-Rahman, Achmus 2005; API 2000; EAU 2004; Feld 2001; Ibsen 2008), the full response of these structures under various loading conditions has not been extensively examined.

In the present study, field tests were performed on bucket foundations installed in Baltic clay to obtain insight into the vertical load response. The field tests were complemented by finite element numerical simulations to provide a better understanding of the parameters influencing the foundation behaviour.

\section{The clay test site}

Clay minerals are the main constituents of most marine sediments. In order to study the behaviour of bucket foundations under various loading conditions, a series of field tests were carried out at the Aalborg University clay test site. The test site is located in Northern Jutland on the outskirts of Aalborg (Grinsted), Denmark on a marine plain formed during the Yoldia transgression period, in connection with the ice retreat from Northern Jutland (approximately 13,000-9,000 years B.C). The clay is a deposit from the Yoldia Sea and is often referred to as Baltic clay. To a depth of approximately $2 \mathrm{~m}$ the soil consists of a brownish-gray clay with a high silt content containing mixtures of silt, sand, and chalk in horizontal stripes of approximately $1 \mathrm{~mm}$. High percentages of illite and low kaolinite/chlorite and quartz/feldspar ratios are characteristic of this marine deposit. Clay mineral assemblages are characterized by an increase in kaolinite/chlorite ratios moving from late glacial to Holocene sediments (Gingele, Leipe 1997). In contrast to other marine sediments such as those in the Mediterranean, the Baltic Sea may be considered as a temporarily inundated portion of the European continent, with salinities ranging from $20-30 \%$ in the Belt Sea to less than 3\% in the Bothnian Bay (Matthaus 1992). The location of the clay test site and the soil layering are depicted in Figures 2 and 3.

\section{Experimental work}

Experiments were conducted to determine the strength and deformation of the clay, including in-situ cone penetration (CPTU) and vane shear tests. The CPTU used in the field tests is illustrated in Figure 4, and the test results are summarized in Tables 1 and 2. 


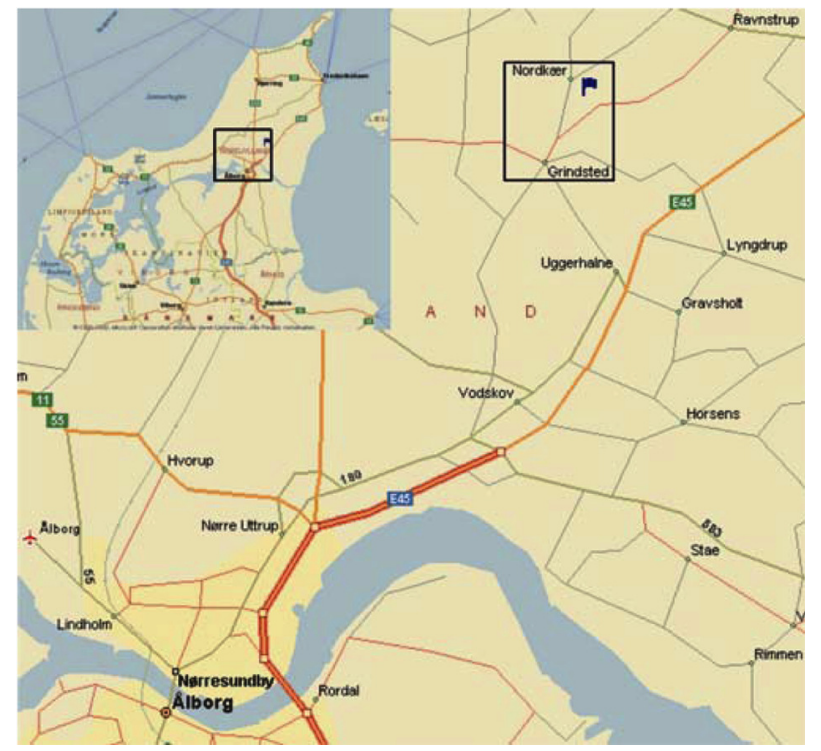

Fig. 2. Study area in Grinsted, north Jutland

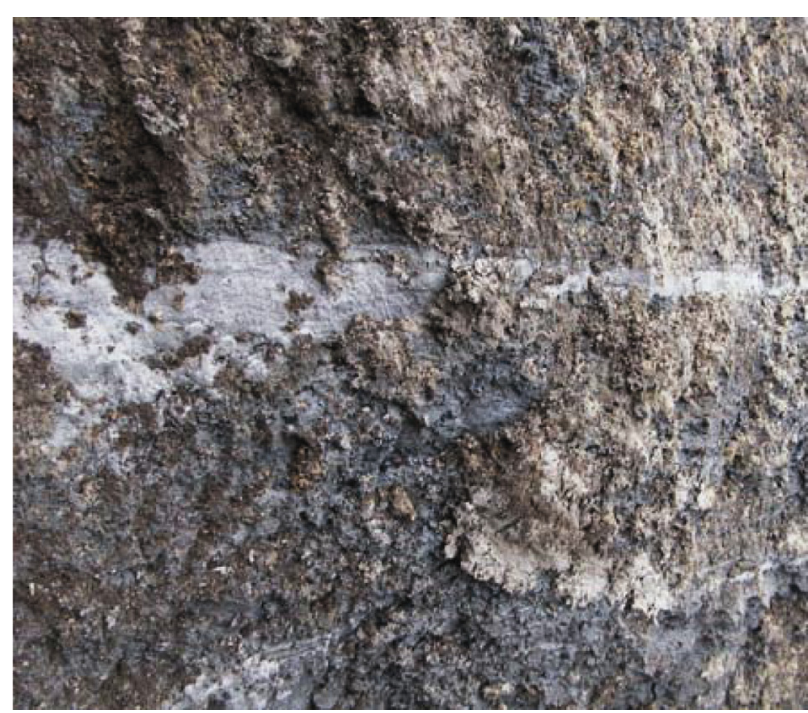

Fig. 3. Illustration of the layering in the soil in Grindsted

Classification experiments were also carried out in the soil mechanics laboratory at Aalborg University according to the "Guidelines on the performance of geotechnical classification" by Wiley Lund. These included water content, grain density, void ratio, Atterberg limits, and hydrometer tests. Table 3 lists the characteristic values for Yoldia clay. A comparison of the Yoldia clay values with the average values obtained in the classification experiments revealed excellent agreement (Table 4). The hydrometer analysis resulted in poor graded curve (Fig. 5).

Bucket foundations are often subjected to a combination of loading conditions including vertical loads and moments. The experiments were performed on a small scale bucket foundation, and separate tests were performed in which vertical loads and bending moments (Barari, Ibsen 2012) were imposed on the foundation via a special loading apparatus designed specifically for bucket foundations.

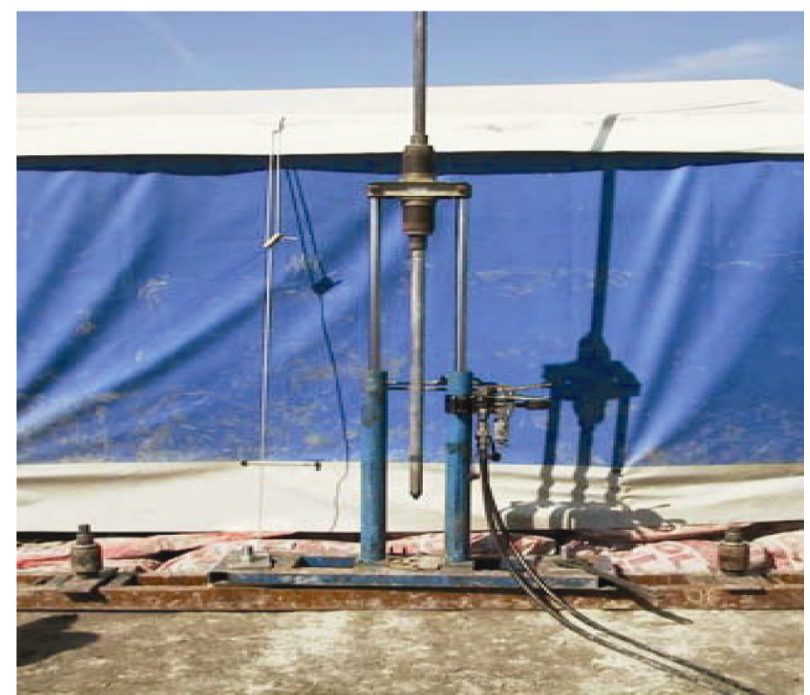

Fig. 4. CPTU test apparatus

Table 1. Experimental $c_{u}$ values (Ibsen, Barari 2011)

\begin{tabular}{lccccc}
\hline \multicolumn{1}{c}{ Test } & $(1)$ & $(2)$ & $(3)$ & $(4)$ & $(5)$ \\
\hline $\begin{array}{l}\text { Borehole } \\
\text { A- } c_{u}(\mathrm{kPa})\end{array}$ & 74.36 & 74.41 & 76.24 & 82.06 & - \\
$\begin{array}{l}\text { Borehole } \\
\mathrm{B}-c_{u}(\mathrm{kPa})\end{array}$ & 88.4 & 99.21 & 91.55 & 83.09 & 87.33 \\
$\begin{array}{l}\text { Borehole } \\
\mathrm{C}-c_{u}(\mathrm{kPa})\end{array}$ & 108.47 & 93.41 & 98.51 & 108.38 & 108.47 \\
$\begin{array}{l}\text { Borehole } \\
\mathrm{D}-c_{u}(\mathrm{kPa}) \\
\text { Borehole } \\
\mathrm{E}-c_{u}(\mathrm{kPa})\end{array}$ & 88.18 & 88.73 & - & - & - \\
\hline
\end{tabular}

Table 2. Data obtained from vane shear tests (Ibsen, Barari 2011)

\begin{tabular}{cccc}
\hline Depth $(\mathrm{m})$ & $c_{v}[\mathrm{kPa}]$ & $c_{v r}[\mathrm{kPa}]$ & $S_{t}$ (sensitivity) \\
\hline 0.2 & 147.45 & 33.82 & 4.36 \\
\hline 0.6 & 145.72 & 36.99 & 3.94 \\
\hline 1 & 143.31 & 39.07 & 3.67 \\
\hline
\end{tabular}

Table 3. Characteristic properties of Yoldia clay

\begin{tabular}{ccccccc}
\hline$G_{S}$ & $\gamma$ & $e$ & $W$ & $L L \%$ & $P L \%$ & $I_{p} \%$ \\
\hline $2.7-2.75$ & $19-20$ & $0.8-1$ & $28-30$ & $45-65$ & $20-25$ & $25-40$ \\
\hline
\end{tabular}

Table 4. Characteristic properties of Grindsted clay

\begin{tabular}{ccccccc}
\hline$G_{s}$ & $\gamma$ & $e$ & $W$ & $L L \%$ & $P L \%$ & $I_{p} \%$ \\
\hline 2.73 & 18.61 & 0.85 & 28.27 & 55.91 & 26.62 & 29.29 \\
\hline
\end{tabular}

The foundations were installed by applying pressure to the top of the bucket using a hydraulic cylinder to ensure penetration at a predefined rate of $1.4 \mathrm{~mm} / \mathrm{s}$ (Fig. 6). Loading of the bucket continued until the bucket skirt fully penetrated the soil and the top plate was in contact with the ground surface. The installation rate was the 
same as the rate employed for previous tests in sand. After installation, the hydraulic cylinder was removed and the engine was mounted to the red beams in Figure 7. The experimental apparatus consisted of two $1.5 \mathrm{~m}$ vertical legs on which were placed two horizontal beams with spans of $2.25 \mathrm{~m}$. The legs were inserted into the soil to a depth of approximately $1.5 \mathrm{~m}$. The hydraulic cylinder and bucket foundation were attached to the beams. The vertical loading experiments required addition of a brace (Fig. 8) to the apparatus to prevent rotation of the threaded rod.

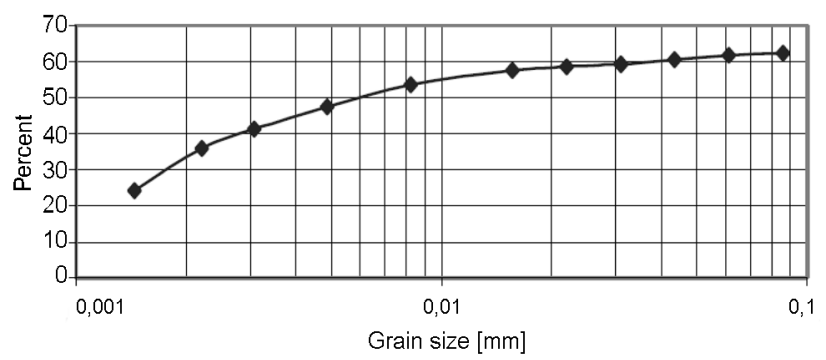

Fig. 5. Average size distribution of eight soil samples from test site

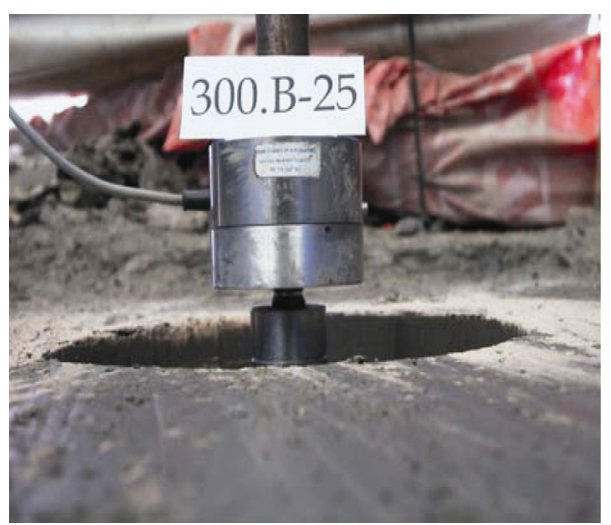

Fig. 6. Installation of bucket foundation $(D=30 \mathrm{~cm}$, embedment ratio 0.25 )

The tests were performed on level ground in order to ensure uniform load transmission from the bucket to the foundation during soil penetration. Levelling of the test area was achieved by embedding metal bars in the soil, levelling the bars, and grading the soil surface by passing a metal scraper along the bars.

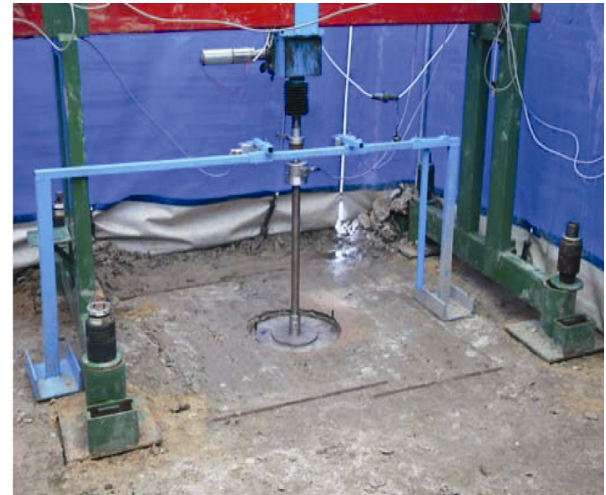

Fig. 7. Bucket load test device used for performing vertical load tests

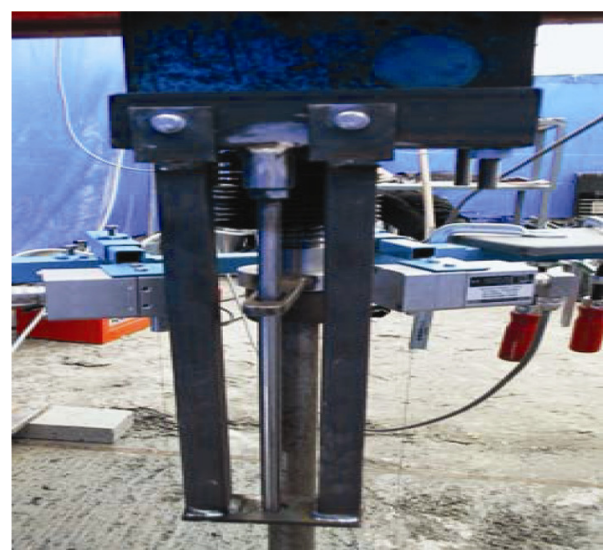

Fig. 8. Hanger bar reinforcement for vertical load tests

Bucket diameters of 20,30 , and $40 \mathrm{~cm}$ and various embedment ratios were considered for the mechanical tests. During previous plate load tests using $40 \mathrm{~cm}$ buckets, failure occurred around the soil edges at loads of approximately $50 \mathrm{kN}$, which resulted in the structure slowly rising from the surface (Fig. 9). Load tests were therefore conducted on bucket foundations with 20 and $30 \mathrm{~cm}$ diameters in an experimental area of $100 \times 150 \mathrm{~cm}^{2}$.

\section{Results of field tests}

The bucket foundations were loaded at the same strain rate as had been used in tests of circular surface foundations (Ibsen, Barari 2011), corresponding to a penetration rate of $44 \mathrm{~mm} / \mathrm{h}$ for the $20 \mathrm{~cm}$ buckets and $60 \mathrm{~mm} / \mathrm{h}$ for the $30 \mathrm{~cm}$ buckets.

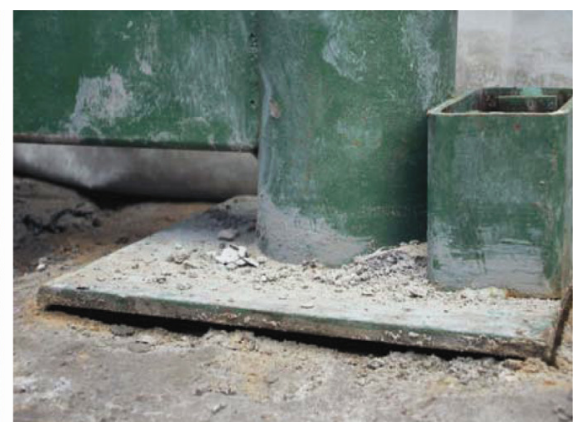

Fig. 9. Plate load test on $40 \mathrm{~cm}$ circular surface foundations 


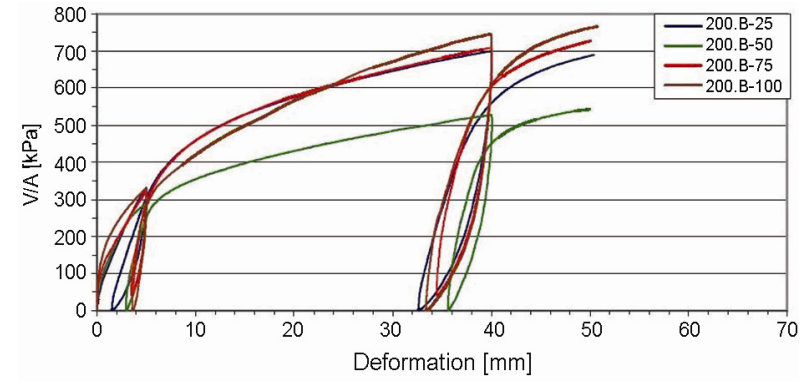

a)

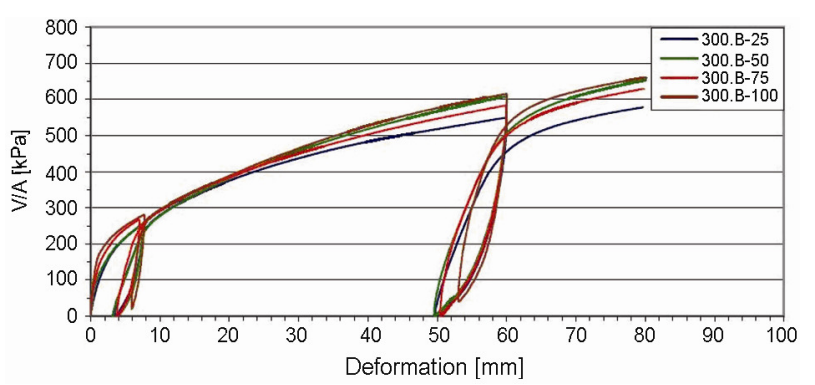

b)

Fig. 10. Stress-displacement curves obtained during 20- and 30-cm diameter bucket tests

The mechanical properties required for the numerical simulations were obtained from the tests. Figure 10 contains the stress-displacement curves from the $20 \mathrm{~cm}$ and $30 \mathrm{~cm}$ diameter bucket tests. Except in the case of the $20 \mathrm{~cm}$ bucket with 0.5 embedment ratio, the variation of skirt length had little effect on the bearing capacity. The results observed using the $20 \mathrm{~cm}$ bucket with an embedment ratio of 0.5 may be attributed to silt stripes present in the vicinity of the test area. The modulus of elasticity $E$ was extracted from the loading test results for use in the numerical analyses (Tables 5 and 6).

Table 5. E-moduli calculated from experiments using $20-\mathrm{cm}$ bucket foundations

\begin{tabular}{cccccc}
\hline Models & $\begin{array}{c}E_{u r} \\
{[\mathrm{kPa}]}\end{array}$ & $\begin{array}{c}E_{25} \\
{[\mathrm{kPa}]}\end{array}$ & $\begin{array}{c}E_{30} \\
{[\mathrm{kPa}]}\end{array}$ & $\begin{array}{c}E_{40} \\
{[\mathrm{kPa}]}\end{array}$ & $\begin{array}{c}E_{50} \\
{[\mathrm{kPa}]}\end{array}$ \\
\hline $\begin{array}{c}D=20 \mathrm{~cm}, \\
d / D=0.25\end{array}$ & 31920 & 8795 & 8263 & 7329 & 6582 \\
\hline $\begin{array}{c}D=20 \mathrm{~cm}, \\
d / D=0.5\end{array}$ & 33286 & 10720 & 9433 & 7618 & 6078 \\
\hline $\begin{array}{c}D=20 \mathrm{~cm}, \\
d / D=0.75\end{array}$ & 33779 & 8340 & 6877 & 5602 & 4855 \\
\hline $\begin{array}{c}D=20 \mathrm{~cm}, \\
d / D=1\end{array}$ & 32727 & 13087 & 9419 & 5660 & 3978 \\
\hline
\end{tabular}

The incidence of failures resulting in earth movement around the loaded buckets decreased with increasing embedment ratio. For $20 \mathrm{~cm}$ buckets the failure lines were approximately $1.7 \mathrm{~cm}, 1.5 \mathrm{~cm}, 1 \mathrm{~cm}$, and $2 \mathrm{~mm}$ at embedment ratios of $0.25,0.50,0.75$, and 1 . For $30 \mathrm{~cm}$ buckets almost no movements in excess of $2 \mathrm{~mm}$ were observed (Fig. 11).
Table 6. E-moduli calculated from experiments using 30-cm bucket foundations

\begin{tabular}{cccccc}
\hline Models & $\begin{array}{c}E_{u r} \\
{[\mathrm{kPa}]}\end{array}$ & $\begin{array}{c}E_{25} \\
{[\mathrm{kPa}]}\end{array}$ & $\begin{array}{c}E_{30} \\
{[\mathrm{kPa}]}\end{array}$ & $\begin{array}{c}E_{40} \\
{[\mathrm{kPa}]}\end{array}$ & $\begin{array}{c}E_{50} \\
{[\mathrm{kPa}]}\end{array}$ \\
\hline $\begin{array}{c}D=30 \mathrm{~cm}, \\
d / D=0.25\end{array}$ & 32250 & 10345 & 9242 & 6520 & 4690 \\
\hline $\begin{array}{c}D=30 \mathrm{~cm}, \\
d / D=0.5\end{array}$ & 23402 & 9411 & 7609 & 4939 & 3730 \\
\hline $\begin{array}{l}D=30 \mathrm{~cm}, \\
d / D=0.75\end{array}$ & 32133 & 13569 & 10320 & 6252 & 3831 \\
\hline $\begin{array}{c}D=30 \mathrm{~cm}, \\
d / D=1\end{array}$ & 33766 & 19107 & 12535 & 5730 & 3294 \\
\hline
\end{tabular}

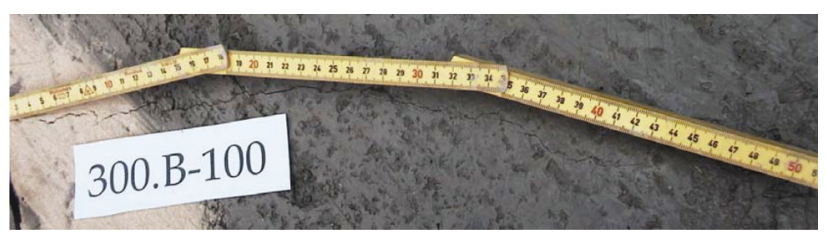

Fig. 11. Failure line in surrounding soil after testing $30 \mathrm{~cm}$ foundation

\subsection{Strength of transition zone using $\alpha$-method}

As the bucket is inserted in the soil, a thin transition zone forms between the bucket surface and the surrounding area. An accurate numerical model of the bucket foundation should incorporate a realistic estimate of the strength of this zone, which may be determined using the $\alpha$ method. This approach was initially used to determine the undrained bearing capacity of offshore piles. In pile loading tests the total capacity of the pile $Q_{T}$ is initially determined, and $Q_{m}$ is calculated by subtracting the rough calculated resistance $Q_{p}$ from $Q_{T}$.

The shaft resistance may be expressed as:

$$
f=Q_{m} / A_{m}=\alpha c_{u} .
$$

Several authors have developed formulas or curves for the variation of $\alpha$ with $c_{u}$ (Peck et al. 1953; Woodward et al. 1961; Kerisel 1961). There are large differences in the $\alpha$-values values determined using different formulas (Fig. 12).

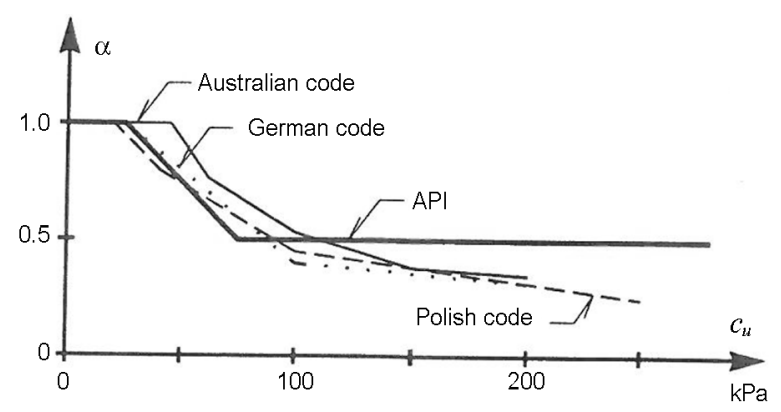

Fig. 12. $\alpha$-values obtained using different codes 
Table 7. Undrained shear strengths calculated analytically using bearing capacity formula

\begin{tabular}{lcccccccc}
\hline & $20 \mathrm{~cm}-\mathrm{d} / \mathrm{D}=$ & $20 \mathrm{~cm}-\mathrm{d} / \mathrm{D}=$ & $20 \mathrm{~cm}-\mathrm{d} / \mathrm{D}=$ & $20 \mathrm{~cm}-\mathrm{d} / \mathrm{D}=30 \mathrm{~cm}-\mathrm{d} / \mathrm{D}=$ & $30 \mathrm{~cm}-\mathrm{d} / \mathrm{D}=$ & $30 \mathrm{~cm}-\mathrm{d} / \mathrm{D}=$ & $30 \mathrm{~cm}-\mathrm{d} / \mathrm{D}=$ \\
& 0.25 & 0.5 & 0.75 & 1 & 0.25 & 0.5 & 0.75 & 1 \\
\hline$c_{u}[\mathrm{kPa}]$ & 113.05 & 85.08 & 114.31 & 120.1 & 88.61 & 97.97 & 93.59 & 98.61 \\
\hline$c_{u, d c}[\mathrm{kPa}]$ & 97.7 & 68.36 & 85.82 & 88.99 & 76.58 & 78.71 & 70.27 & 73.07 \\
\hline
\end{tabular}

Although the codes are in reasonable agreement with pile loading test results, it is clear that additional factors should be included. For instance, many authors have noted that $\alpha$ depends on the overconsolidation ratio (OCR) (McCelland 1974; Semple, Rigden 1984). Figure 13 is a plot of the $\alpha$ values derived from our results as a function of undrained clay shear strength.

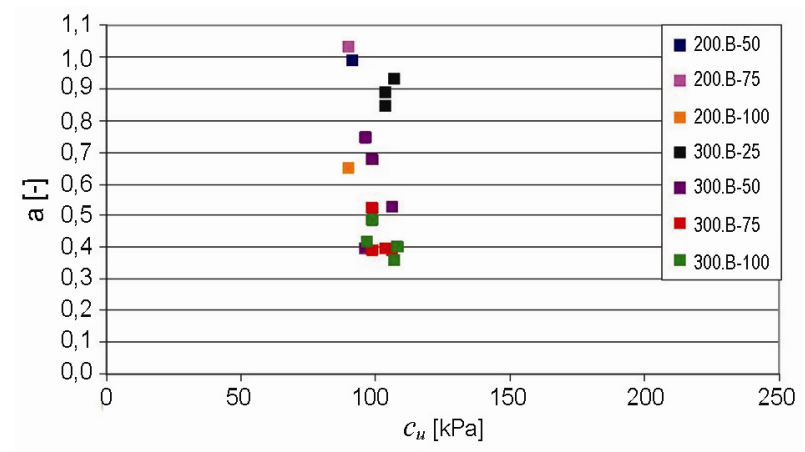

Fig. 13. $\alpha$-values with respect to undrained shear strength of clay

\subsection{Effect of embedment on the shear strength values}

A general bearing capacity equation was developed based on the load test results. The equation models the bucket as a surface foundation in which the foundation surface is located at a certain depth below the soil surface. The general bearing capacity equation is:

$$
b=\frac{Q}{A}=c_{u, d c} N_{c} S_{c} i_{c} d_{c}+q .
$$

The undrained shear strength of the buckets was measured twice in order to investigate the influence of depth factor. The depth factor was calculated from Brinch Hansen's $(1961,1970)$ expression:

$$
d_{c}=1+0.35 \frac{\bar{D}}{D},
$$

in which $\bar{D}$ is the effective depth and $D$ is the diameter of the foundation. The effective depth is the minimum depth below the surface at which the soil possesses at least the same strength as the soil beneath the foundation plate. The effective depth was initially equal to the skirt length and increased with increasing vertical load on the foundation. The depth factor should not assume values greater than 1.35. The undrained shear strengths calculated using Eqn (2) are listed in Table 7.

\section{Finite element model}

\subsection{Mesh}

Two-dimensional finite element models of the test apparatus were developed in order to obtain realistic numerical models of the bucket foundation system. In order to take advantage of symmetry, the model reflected only half of the physical structure.

A number of mesh densities were investigated to achieve a time-efficient model without compromising accuracy. Since there is a high stress and strain concentration near the bucket foundation and the intensity of stress and strain diminishes further from the bucket, a special discretization mesh was developed. The mesh in Figure 14 comprises three distinct regions differing in mesh size, beginning with a very fine six-node triangular mesh in a trapezoidal region near the bucket and moving to coarser mesh regions away from the bucket while retaining the six-node triangular elements. The axisymmetric model consisted of approximately 1400 elements. Boundary conditions were selected so that both sides were restrained against horizontal movements and the bottom horizontal boundary was restrained against horizontal as well as vertical movements. The node at the left vertical boundary representing the bucket foundation was restrained against rotation.

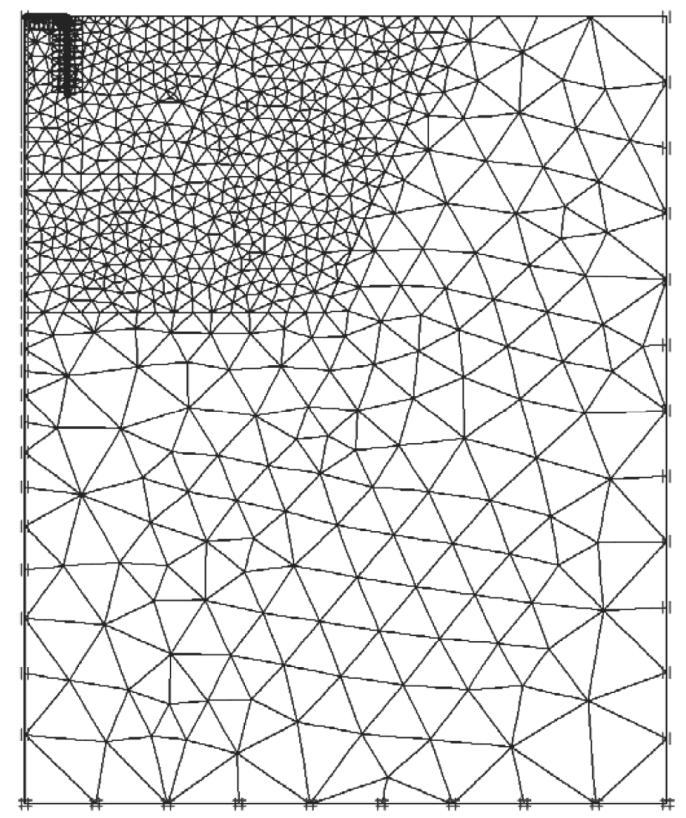

Fig. 14. Finite element mesh of bucket foundation under vertical loading 


\subsection{Material properties}

The soil conditions were modelled using an elastic-purely plastic Mohr-Coulomb constitutive model with a uniform undrained shear strength/depth profile. Although the Mohr-Coulomb model is unable to capture post-yield behaviours such as hardening or softening, this was unimportant since the interest of this study was to determine the failure stress level. The bucket foundation was assumed to exhibit linear elastic behaviour.

The physical and mechanical properties of the clay including $E, c_{u}, v=0.495$ and $\gamma=19 \mathrm{kN} / \mathrm{m}^{3}$ were determined from laboratory tests performed on field samples. The properties of the bucket foundation simulations were based on the properties of the buckets used in the field tests (Table 8). The undrained shear strength and elasticity modulus of the soil were varied in a parametric analysis in order to investigate their effect on the bearing capacity of the bucket foundation under vertical loading.

Table 8. Material parameters for bucket foundations

\begin{tabular}{ccccc}
\hline Diameter & $\begin{array}{c}\mathrm{EA} \\
(\mathrm{kN} / \mathrm{m})\end{array}$ & $\begin{array}{c}\mathrm{EI} \\
\left(\mathrm{kN} \cdot \mathrm{m}^{2} / \mathrm{m}\right)\end{array}$ & $\begin{array}{c}W \\
(\mathrm{kN} / \mathrm{m})\end{array}$ & $v$ \\
\hline $20 \mathrm{~cm}$ & $6.594 \times 10^{6}$ & 16493 & 0 & 0.3 \\
\hline $30 \mathrm{~cm}$ & $1.4844 \times 10^{7}$ & 79521 & 0 & 0.3 \\
\hline
\end{tabular}

\section{Analyses}

A series of parametric studies were performed to obtain the best fit curves for vertical bearing capacity of bucket foundations employing various moduli. In this section the finite element simulations are compared with the behaviour observed during field tests. In the vertical loading simulations, the load-displacement curves were fit by varying the soil parameters $E$ and $C_{u}$ in the simulations. The interface between the soil and the foundation was
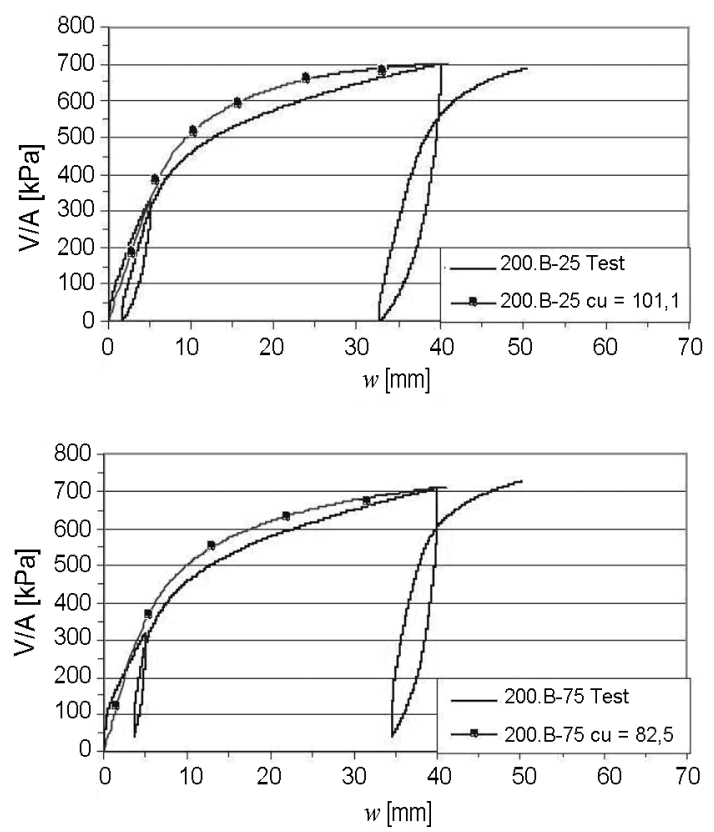

assumed to be fully bonded, which is a relevant consideration in offshore foundations. The suction developed within the soil plug during loading provides a capacity to resist tensile loading conditions. Undrained conditions may be present for months or years due to the large size of offshore foundations (i.e. $15000 \mathrm{~m}^{2}$ in plane area).

The load-displacement relationship is illustrated in Figures 15 and 16. In the numerical simulations, the value of $c_{u}$ was modified to achieve the best fit with the experimental data. A similar procedure was followed with the modulus of the soil, in which values of $25 \%$, $30 \%, 40 \%$, and $50 \%$ and $E_{25}$ is then chosen to reach the best agreement with the field data. The results of the vertical loading analyses are summarized in Tables 9 and 10.

\subsection{Ultimate loads}

In order to demonstrate the effects of embedment ratio and foundation diameter, failure values under pure vertical loading were analyzed. Tables 11 and 12 contain the values of the ultimate vertical load $\left(F_{\text {Vult }}\right)$ for 20 and $30 \mathrm{~cm}$ surface and bucket foundations on Yoldia clay evaluated using finite element analysis, as well as relevant literature data. Bucket foundations with a skirt length ratio of 0.5 were selected for validation. The calculated ultimate bearing capacities under pure vertical loads $\left(F_{V u l t}\right)$ for circular surface foundations on Yoldia clay were $76.6 \mathrm{kN}$ for $20 \mathrm{~cm}$ foundations and $132.5 \mathrm{kN}$ for $30 \mathrm{~cm}$ foundations, very close to the exact solutions proposed by Shield (1955) and the finite element results of Gourvenec and Randolph (2002).

The behaviour presented in the figures and Tables highlights the significant sensitivity of the bearing capacity to the skirt length ratio (e.g. a $37 \%$ increase in pure bearing capacity for the two cases moving from $d / D=0$ to $d / D=0.5$ ).
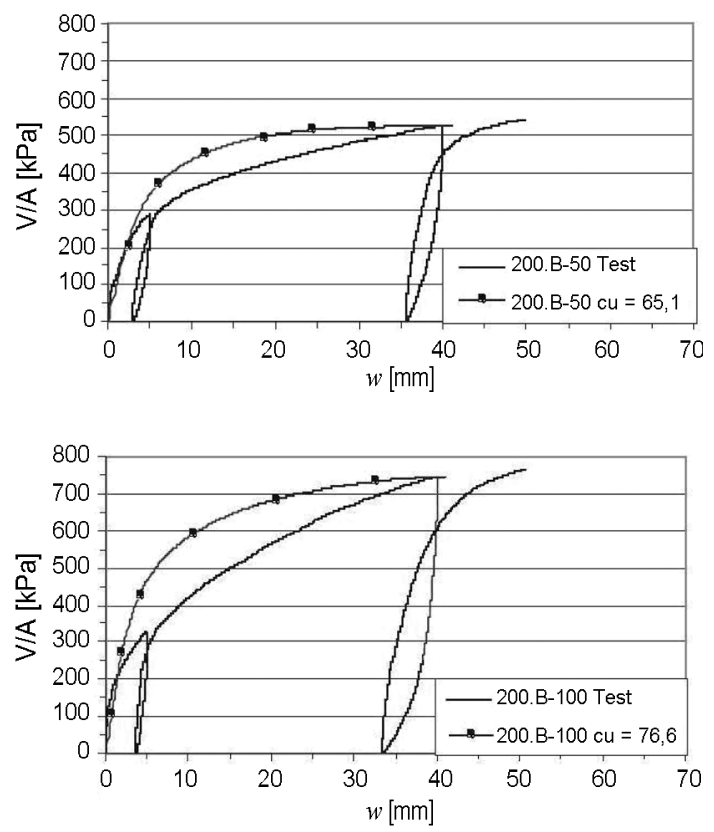

Fig. 15. Best fit curve for load-displacement data from field tests for vertical loading of 20-cm bucket foundation 

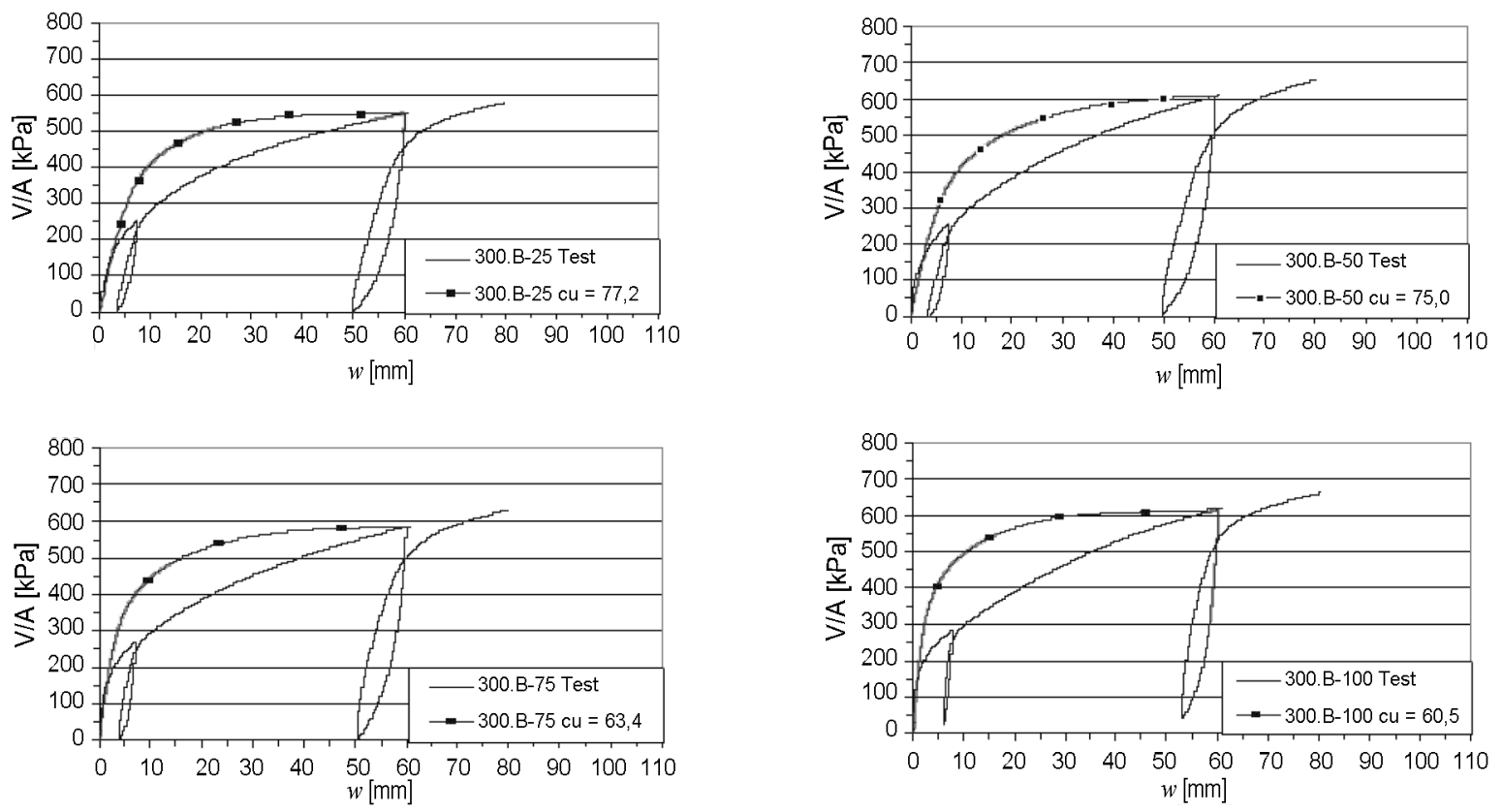

Fig. 16. Best fit curve for load-displacement data from field tests for vertical loading of $30-\mathrm{cm}$ bucket foundation

Table 9. Results of best-fit finite element simulations

\begin{tabular}{|c|c|c|c|c|}
\hline Type of Foundation & Type of Simulation & Deformation (mm) & Failure Value [kPa] & Error (Deviation) \\
\hline \multirow[t]{3}{*}{$\begin{array}{c}D=20 \mathrm{~cm} \\
d / D=0.25\end{array}$} & $\begin{array}{c}\text { FEM } \\
c_{u}=101.2[\mathrm{kPa}]\end{array}$ & 39.98 & 699.79 & +0.087 \\
\hline & $\begin{array}{c}\text { FEM } \\
c_{u}=101.1[\mathrm{kPa}]\end{array}$ & 39.98 & 699.15 & -0.004 \\
\hline & Experiment & 39.98 & 699.18 & - \\
\hline \multirow[t]{3}{*}{$\begin{array}{l}D=20 \mathrm{~cm} \\
d / D=0.5\end{array}$} & $\begin{array}{c}\text { FEM } \\
c_{u}=65.1[\mathrm{kPa}]\end{array}$ & 40 & 527.13 & -0.064 \\
\hline & $\begin{array}{c}\text { FEM } \\
c_{u}=65.2[\mathrm{kPa}]\end{array}$ & 40 & 527.9 & 0.082 \\
\hline & Experiment & 40 & 527.47 & - \\
\hline \multirow[t]{2}{*}{$\begin{array}{c}D=20 \mathrm{~cm} \\
d / D=0.75\end{array}$} & $\begin{array}{c}\text { FEM } \\
c_{u}=82.5[\mathrm{kPa}]\end{array}$ & 39.98 & 708.58 & -0.021 \\
\hline & $\begin{array}{c}\text { FEM } \\
c_{u}=82.6[\mathrm{kPa}]\end{array}$ & 39.98 & 709.32 & +0.083 \\
\hline \multirow[t]{3}{*}{$\begin{array}{c}D=20 \mathrm{~cm} \\
d / D=1\end{array}$} & $\begin{array}{c}\text { Experiment } \\
\text { FEM } \\
c_{u}=76.5[\mathrm{kPa}]\end{array}$ & $\begin{array}{l}39.98 \\
39.98\end{array}$ & $\begin{array}{l}708.73 \\
744.55\end{array}$ & $\frac{-}{-0.102}$ \\
\hline & $\begin{array}{c}\text { FEM } \\
c_{u}=76.6[\mathrm{kPa}]\end{array}$ & 39.98 & 745.44 & 0.017 \\
\hline & Experiment & 39.98 & 745.31 & - \\
\hline
\end{tabular}

\subsection{Comparison with the stress characteristics method}

According to plasticity theory (Davis 1968), the stress characteristic method is capable of an exact solution for a rigid, perfectly plastic material under plane strain conditions. With undrained saturated clay, the normality condition is reasonably postulated as $\phi=\psi=0^{\circ}$. The same technique may be used for axisymmetric problems, although the relationship of the solution to the exact one for a rigid, perfectly plastic material is no longer clear be- cause of the failure to satisfy the normality condition (Houlsby, Wroth 1983).

The numerical analysis failure values obtained for the bucket foundations exhibit excellent agreement with the plasticity stress characteristic values presented by Houlsby and Wroth (1983). The current solutions should be considered upper bounds, unless it can be shown that lower bounds exist with the same failure values (Tables 11 and 12). In addition, the finite element results for bucket foundations were validated against the plasticity results presented by Martin (2001) for circular foundations. Sur- 
prisingly, the collapse loads for circular foundations obtained using plasticity solutions fall just below the numerical and experimental simulation results obtained for bucket foundations.

\subsection{Ultimate vertical capacity depth factors}

Figure 17 illustrates the variation in normalized vertical limit state $\left(N_{c V}=\left(\frac{V_{u l t}}{D c_{u}}\right)\right)$ with respect to embedment ratio for bucket foundations, as well as a comparison with previous numerical analyses in the literature for circular foundations (Bransby, Randolph 1999; Gourvenec 2008). The results are normalized with respect to foundation area (i.e. for plane strain the area is equal to the diameter), and undrained shear strength.
Embedment increases the vertical capacity as the failure regions are forced deeper within the soil mass. Classical bearing capacity theory uses depth factors proposed by Skempton (1951) and Brinch Hansen (1970) to modify the uniaxial vertical bearing capacity, and recommended industry practices are based on these factors (e.g. Eqn (4)):

$$
d_{c V}=0.3 e^{-0.5 k D / c_{u 0}} \arctan (d / D),
$$

$k$ is the gradient of the undrained shear strength profile (equal to zero for homogeneous deposits). Classical depth factors were originally derived for smooth-sided circular foundations but are also widely used for rough, smoothsided, strip, and three dimensional foundations.

Table 10. Results of best-fit finite element simulations

\begin{tabular}{|c|c|c|c|c|}
\hline Type of Foundation & Type of Simulation & Deformation (mm) & Failure Value $[\mathrm{kPa}]$ & Error (Deviation) \\
\hline \multirow[t]{3}{*}{$\begin{array}{c}D=30 \mathrm{~cm} \\
d / D=0.25\end{array}$} & $\begin{array}{c}\text { FEM } \\
c_{u}=77.1[\mathrm{kPa}]\end{array}$ & 59.96 & 548.60 & -0.113 \\
\hline & $\begin{array}{c}\text { FEM } \\
c_{u}=77.2[\mathrm{kPa}]\end{array}$ & 59.96 & 549.28 & 0.011 \\
\hline & Experiment & 59.96 & 549.22 & - \\
\hline \multirow[t]{3}{*}{$\begin{array}{l}D=30 \mathrm{~cm} \\
d / D=0.5\end{array}$} & $\begin{array}{c}\text { FEM } \\
c_{u}=75[\mathrm{kPa}]\end{array}$ & 59.99 & 608.38 & -0.015 \\
\hline & $\begin{array}{c}\text { FEM } \\
c_{u}=75.1[\mathrm{kPa}]\end{array}$ & 59.99 & 609.13 & 0.108 \\
\hline & Experiment & 59.99 & 608.47 & - \\
\hline \multirow[t]{3}{*}{$\begin{array}{c}D=30 \mathrm{~cm} \\
d / D=0.75\end{array}$} & $\begin{array}{c}\text { FEM } \\
c_{u}=63.3[\mathrm{kPa}]\end{array}$ & 59.92 & 581.99 & -0.134 \\
\hline & $\begin{array}{c}\text { FEM } \\
c_{u}=63.4[\mathrm{kPa}]\end{array}$ & 59.92 & 582.85 & +0.014 \\
\hline & Experiment & 59.92 & 582.77 & - \\
\hline \multirow[t]{3}{*}{$\begin{array}{c}D=30 \mathrm{~cm} \\
d / D=1\end{array}$} & $\begin{array}{c}\text { FEM } \\
c_{u}=60.4[\mathrm{kPa}]\end{array}$ & 60.01 & 614.42 & -0.112 \\
\hline & $\begin{array}{c}\text { FEM } \\
c_{u}=60.5[\mathrm{kPa}]\end{array}$ & 60.01 & 615.37 & 0.042 \\
\hline & Experiment & 60.01 & 615.11 & - \\
\hline
\end{tabular}

Table 11. Comparison to published data

\begin{tabular}{|c|c|c|c|c|c|}
\hline & $\begin{array}{l}\text { Current } \\
\text { research }\end{array}$ & $\begin{array}{l}\text { Gourvenec, Randolph } \\
\text { (2002) }\end{array}$ & $\begin{array}{l}\text { Shield } \\
(1955)\end{array}$ & $\begin{array}{l}\text { Houlsby, Wroth } \\
\text { (1983) }\end{array}$ & $\begin{array}{l}\text { Martin } \\
(2001)\end{array}$ \\
\hline $\begin{array}{l}\text { Bucket Foundation }(20 \mathrm{~cm}) \\
d / D=0.5, c_{u}=65.1[\mathrm{kPa}]\end{array}$ & 105.42 & 97.12 & - & 99.082 & 99.34 \\
\hline $\begin{array}{l}\text { Circular Footing }(20 \mathrm{~cm}) \\
c_{u}=65.1[\mathrm{kPa}]\end{array}$ & 76.6 & 76.94 & 78.77 & - & - \\
\hline
\end{tabular}

Table 12. Comparison to published data

\begin{tabular}{|c|c|c|c|c|c|}
\hline & $\begin{array}{l}\text { Current } \\
\text { research }\end{array}$ & $\begin{array}{c}\text { Gourvenec, Randolph } \\
(2002)\end{array}$ & $\begin{array}{l}\text { Shield } \\
(1955) \\
\end{array}$ & $\begin{array}{c}\text { Houlsby, Wroth } \\
(1983)\end{array}$ & $\begin{array}{l}\text { Martin } \\
(2001) \\
\end{array}$ \\
\hline $\begin{array}{l}\text { Bucket Foundation }(30 \mathrm{~cm}) \text {, } \\
d / D=0.5, c_{u}=75[\mathrm{kPa}]\end{array}$ & 182.51 & 167.85 & - & 171.22 & 171.67 \\
\hline $\begin{array}{l}\text { Circular Footing }(30 \mathrm{~cm}) \\
\qquad c_{u}=75[\mathrm{kPa}]\end{array}$ & 132.5 & 132.97 & 136.12 & - & - \\
\hline
\end{tabular}




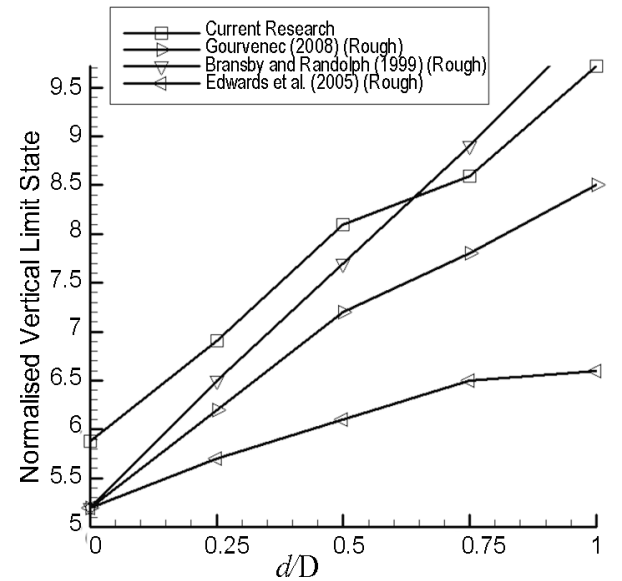

Fig. 17. Ultimate vertical bearing capacity as a function of embedment ratio for Yoldia clay

For pure vertical loading, Meyerhof (1953) and Brinch Hansen (1970) also approximated the depth factor for strip or circular foundations as a linear fraction relative to $d / D$ :

$$
\begin{aligned}
& d_{c V}=1+n\left(\frac{d}{D}\right), \\
& 0.2 \subseteq n \subseteq 0.4 .
\end{aligned}
$$

The analyses describe a quadratic relationship between the ultimate uniaxial vertical load and the embedment ratio, which can be presented in terms of a depth factor:

$$
d_{c V}=1.0036+0.7138 \frac{d}{D}-0.0766\left(\frac{d}{D}\right)^{2} .
$$

Eqn (6) has been verified only for skirt lengths between 0 and 1. Tani and Craig (1995) carried out lower bound plasticity analyses and centrifuge tests to investigate the vertical capacity of skirted foundations in nonhomogeneous soils. They showed that, the soil above the level of the skirt tips for strip footings does not contribute to the vertical bearing capacity, while for circular footings its contribution was small.

Given the conclusions of Tani and Craig (1995), analyses of small scale bucket foundations suggested that, for pure vertical bearing capacity, the load-displacement curves are dependent on the foundation type and embedment depths.

Recent research has challenged the use of these conventional modification factors and explored the extent to which capacity is enhanced and the failure mode is changed with increasing embedment ratio. The trend of increasing capacity with increasing embedment does not continue indefinitely owing to a change in failure mode (Fig. 18), confirming the behaviour proposed by Yun and Bransby (2007) for rough embedded strip foundations.

Similar trends have been observed in other model simulations. It has also been noted that a failure mechanism similar to that of a shallow foundation is produced in bucket loading. Measurements have demonstrated that the failure surface beneath the bucket skirt extends to a depth of approximately $D / 2$.

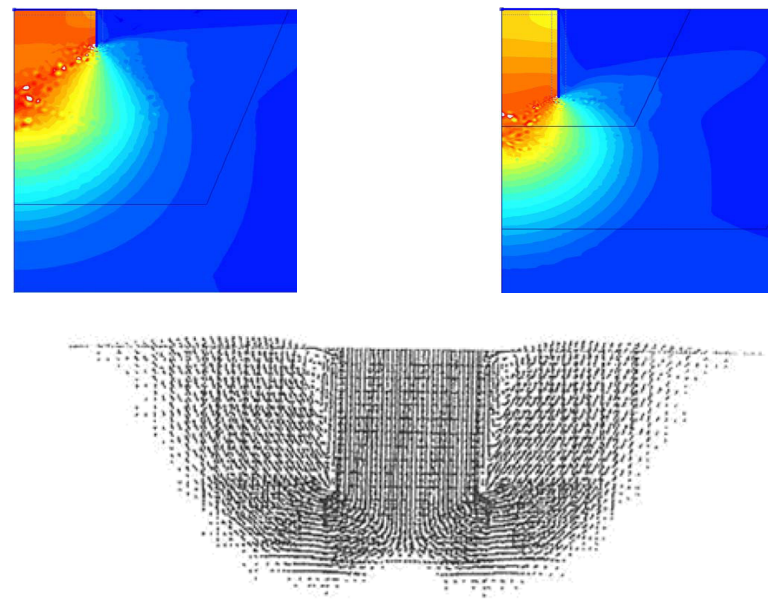

Fig. 18. Comparison of kinematic mechanisms accompanying failure of bucket foundations in homogeneous soil and skirted foundations in normally consolidated soils: a) bucket with embedment ratio 0.25 ; b) bucket with embedment ratio 1 ; c) skirted foundation with embedment ratio 1 (Yun, Bransby 2007)

\section{Conclusions}

A suction bucket foundation is a closed-top steel tube that is lowered to the seafloor, allowed to penetrate the bottom sediments under its own weight, then pushed to full depth under the suction force produced by pumping water out of the interior. Suction foundations are attractive because of their convenient installation and reusability, as well as the fact that they may withstand a significant amount of reverse loading through passive suction during uplift.

Extensive research has been conducted on bucket foundations in sand, leading to a host of theories describing their behaviour in this soil type. However, there has been relatively little research examining bucket foundation behaviour in clay soils. In the present study, we carried out experimental and numerical analyses of bucket foundations under vertical loading in clay soils.

In order to examine the effect of foundation geometry on the load transfer mechanism and the stress distribution within the soil, bucket diameters of $20 \mathrm{~cm}$ and $30 \mathrm{~cm}$ and embedment ratios of $0.25,0.50,0.75$, and 1 were tested.

The Mohr-Coulomb model was sufficient for modelling the initial loading condition, but could not be used to describe post-yield behaviour such as hardening and softening. However, the strains corresponding to peak strength indicate that failure is reached prior to softening, and therefore the fundamental behaviour leading to failure can be effectively modelled using constitutive approaches such as the Mohr-Coulomb model.

Although Tani and Craig (1995) suggested that the bearing capacity of a shallow foundation was independent of the soil strength above the base of the footing (i.e. no embedment effects) for undrained conditions, this finding has not been verified using vertical monotonic loading or finite element analysis while a $37 \%$ increase in pure bearing capacity for the two samples ranging from $d / D=0$ to $d / D=0.5$ is determined .

The results were also compared to plasticity models in order to verify the accuracy of the simulations. A comparison of the variation in normalized vertical limit state 
for circular and bucket foundations was also presented, and the quadratic relationship between ultimate vertical load and embedment ratio was discussed in detail.

In contrast to soils with significant strength heterogeneity (such as normally consolidated deposits) in which a Hill-type mechanism governs failure, soils with a uniform shear strength profile failure are described by a Prandtl-type failure mechanism in which the soil plug tends to move as a rigid block under uniaxial vertical loads. In this case the type of embedment has little effect on bearing capacity.

\section{Nomenclature}

$\begin{array}{ll}c_{u} & \text { Undrained shear strength [kPa] } \\ S_{c} & \begin{array}{l}\text { Dimensionless factor, equal to } 1.2 \text { for circular foun- } \\ \text { dations }\end{array} \\ N_{c} & \text { dimensionless factor } \\ i_{c} & \text { Dimensionless factor, taken as } 1 \text { with } \mathrm{H}=0 \\ d_{c} & \text { Depth factor, taken as } 1.35 \text { for } \mathrm{D} / \mathrm{B}>1 \\ Q & \text { (Brinch Hansen }(1961,1970)[\mathrm{m}] \\ A & \text { Total load at the bucket tip [kPa] } \\ Q_{T} & \text { Total capacity of the pile } \\ G_{S} & \text { Specific gravity } \\ \gamma & \text { Unit weight } \\ e & \text { Void ratio } \\ L L & \text { Liquid limit } \\ P L & \text { Plastic limit } \\ I_{p} & \text { Plasticity index } \\ W & \text { Water content } \\ f & \text { Shaft resistance } \\ c_{u 0} & \text { Undrained shear strength of the soil at foundation } \\ c_{v} & \text { level } \\ & \text { Shear strength from vane shear test }\end{array}$

\section{References}

Aas, P. M.; Andersen, K. H. 1992. Skirted foundation for offshore structure, in Ninth Offshore South East Asia Conference, Singapore, World Trade Center Singapore, Singapore, 1-7.

Abdel-Rahman, K.; Achmus, M. 2005. Finite element modelling of horizontally loaded monopile foundations for offshore wind energy converters in Germany, in International Symposium on Frontiers in Offshore Geotechnics (ISFOG), Perth, Australia.

Achmus, M.; Abdel-Rahman, K. 2005. Design of monopile foundations for offshore wind energy plants, in $11^{\text {th }}$ International Colloquium on Structural and Geotechnical Engineering, Cairo, Egypt.

Allersma, H. G. B.; Kierstein, A. A.; Males, D. 2000. Centrifuge modeling on suction piles under cyclic loading and long term vertical loading, in Proceedings of $10^{\text {th }}$ International Offshore and Polar Engineering Conference, Seattle, USA, International Society of Offshore and Polar Engineers.

Allersma, H. G. B.; Phenevaux, F. J. A.; Wingtgens, J. F. P. C. M. E. 1997. Simulation of suction pile installation in sand in a geocentrifuge, in Proceedings of the $7^{\text {th }}$ International Offshore and Polar Engineering Conference (ISOPE97) 1: 761-765.

Andersen, K. H.; Jostad, H. P. 1999. Foundation design of skirted foundations and anchors in clay, in Proceedings of Offshore Technology Conference, Houston, Texas, OTC 10824, 1-10.

Andersen, L. V.; Vahdatirad, M. J.; Sichani, M. T.; Sørensen, J. D. 2012. Natural frequencies of wind turbines on monopile foundations in clayey soils - a probabilistic approach, Computers and Geotechnics 43: 1-11. http://dx.doi.org/10.1016/j.compgeo.2012.01.010

API 2000. American Petroleum Institute. Recommended practice for planning, designing and constructing fixed offshore platforms - working stress design. API Recommended Practice 2A-WSD (RP2A-WSD). $21^{\text {st }}$ ed. Dallas.

Barari, A.; Ibsen, L. B. 2012. Undrained response of bucket foundations to moment loading, Applied Ocean Research 26: 12-21. http://dx.doi.org/10.1016/j.apor.2012.01.003

Bransby, M. F.; Randolph, M. F. 1999. The effect of skirted foundation shape on response to combined V-M-H loadings, International Journal of Offshore and Polar Engineering 9: 214-218.

Brinch Hansen, J. 1961. A general formula for bearing capacity, Danish Geotechnical Institute Bulletin 11: 38-46.

Brinch Hansen, J. 1970. A revised and extended formula for bearing capacity, 98: 5-11. Copenhagen: The Danish Geotechnical Institute.

Byrne, B. W.; Houlsby, G. T. 2004. Experimental investigations of the responses of suction caissons to transient combined loading, ASCE Journal of Geotechnical and Geoenvironmental Engineering 130: 240-253. http://dx.doi.org/10.1061/(ASCE)1090-0241(2004)130: $3(240)$

Byrne, B. W.; Houlsby, G. T.; Martin, C. M.; Fish, P. M. 2002. Suction caisson foundations for offshore wind turbines, Wind Engineering 26: 145-155. http://dx.doi.org/10.1260/030952402762056063

Clukey, E. C.; Morrison, M. J.; Garnier, J. 1995. The response of suction caissons in normally consolidated clays to cyclic TLP loading conditions, OTC 7797, 909-918.

Davis, E. H. 1968. Theories of plasticity and the failure of soil masses. London: Butterworths, 341-380.

Ding, H.; Qi, L.; Du, X. 2003. Estimating soil liquefaction in ice-induced vibration of bucket foundation, ASCE Journal of Cold Regions Engineering 17(2): 60-67. http://dx.doi.org/10.1061/(ASCE)0887-381X(2003)17: 2(60)

Dyme, W.; Houlsby, G. T. 1998. Drained behavior of suction caisson foundations on very dense sand, in Proc. Offshore Technol. Conf., Houston, OTC 10994, 765-782.

EAU 2004. Empfehlungen des Arbeitsausschusses "Ufereinfassungen" - Häfen und Wasserstraßen. Berlin: Verlag Ernst \& Sohn.

Ebrich, C. T.; Tjelta, T. I. 1999. Installation of bucket foundations and suction caissons in sand: geotechnical performance, in Int. Proc Offshore Technology Conf. Texas. Paper 10990. http://dx.doi.org/10.4043/10990-MS

Edwards, D. H.; Zdravkovic, L.; Potts, D. M. 2005. Depth factors for undrained bearing capacity, Geotechnique 55(10): 755-758.

http://dx.doi.org/10.1680/geot.2005.55.10.755 
Feld, T. 2001. Suction buckets, a new innovative foundation concept, applied to Offshore Wind Turbines: PhD Thesis. Aalborg University, Denmark.

Feld, T. 2006. State-of-the art design standard specific developed and applicable for offshore wind turbine structures. North American Wind Power.

Gingele, F. X.; Leipe, T. 1997. Clay mineral assemblages in the western Baltic Sea: recent distribution and relation to sedimentary unit, Marine Geology 140(1-2): 97-115. http://dx.doi.org/10.1016/S0025-3227(97)00023-6

Gourvenec, S. 2008. Effect of embedment on the undrained capacity of shallow foundations under general loading, Geotechnique 58(3): 177-185.

http://dx.doi.org/10.1680/geot.2008.58.3.177

Gourvenec, S.; Randolph, M. 2002. Effect of strength nonhomogeneity on the bearing capacity of circular skirted foundations subjected to combined loading, in Proceedings of the Twelfth International Offshore and Polar Engineering Conference, Kitakyushu, Japan, 26-31.

Houlsby, G. T.; Byrne, B. W. 2000. Suction caisson foundations for offshore wind turbines and anemometer masts, Wind Eng 24(4): 249-255. http://dx.doi.org/10.1260/0309524001495611

Houlsby, G. T.; Wroth, C. P 1983. Calculation of stresses on shallow penetrometers and footings, in Proc. IUTAM/IUGG Seabed Mechanics, Newcastle, 107-112

Ibsen, L. B. 2008. Implementation of a new foundation concept for offshore wind farms, in Int. Proc $15^{\text {th }}$ Nordic Geotechnical Meeting, Norway, 19-33.

Ibsen, L. B.; Barari, A. 2011. Monotonic loading of circular surface footings on clay, Journal of Mechanical Science and Technology 25(12): 3151-3158. http://dx.doi.org/10.1007/s12206-011-1001-z

Ibsen, L. B.; Barari, A.; Larsen, K. A. 2012. Modified vertical bearing capacity for circular foundations in sand using reduced friction angle, Ocean Engineering 47: 1-6. http://dx.doi.org/10.1016/j.oceaneng.2012.03.003

Ibsen, L. B.; Schakenda, B.; Nielsen, S. A. 2003. Development of the bucket foundation for offshore wind turbines: a novel principle, in Proceedings of the US Wind Energy Conference, 26-28 August, 2003. 12 p.

Ibsen, L. B.; Schakenda, B.; Nielsen, S. A. 2004. Development of the bucket foundation for offshore wind turbines, a novel principle, in Gigawind-Sym. Offshore-Windenergie, Bau- und umwelttechnische Aspekte, Hannover.

Kerisel, J. 1961. Foundations profondes en milieu sableu, in Proc. VI CSMEF, Vol. 2, Paris.

LeBlanc, C. 2009. Design of offshore wind turbine support structures: PhD Thesis, Aalborg University, Denmark.

Liingaard, M. 2006. Dynamic behaviour of suction caissons: $\mathrm{PhD}$ thesis, Aalborg University Denmark.

Martin, C. M. 2001. Vertical bearing capacity of skirted circular foundations on Tresca soil, in Proc. 15 ${ }^{\text {th }}$ ICSMGE 1: 743-746.

Matthaus, W. 1992. Der Wasseraustausch zwischen Nord- und Ostsee, Geogr. Rundsch 44(1): 626-631.
McCelland, B. 1974. Design of deep penetration piles for ocean structures, in Proc. Journal of the Geotechnical Engineering Division, ASCE 100(GT7): 705-747.

Meyerhof, G. G. 1953. The bearing capacity of footings under eccentric and inclined loads, in Proc. $3^{\text {rd }}$ Int. Conf. on SMFE, Zurich, 440-445.

Peck, R. B.; Hanson, W. F.; Thornborn, T. H. 1953. Foundation Engineering. New York: John Wiley \& Sons, Inc. 410 p.

Semple, R. M.; Ridgen, W. J. 1984. Shaft capacity of driven pipe piles in clay, in Meyer, J. R. (Ed.). A Symposium of ASCE Convention, October 1-5, 1984, San Francisco, California, United States.

Senepere, D.; Auvergne, G. A. 1982. Suction anchor piles - a proven alternative to driving or drilling, in Int. Proc $14^{\text {th }}$ Offshore Technology Conference, 3-6 May 1982, Houston, Texas, 483-493. http://dx.doi.org/10.4043/4206-MS

Shield, R. T. 1955. On the plastic flow of metals under conditions of axial symmetry, in Proc. Royal Society London, 20 December, 1955. 223(1193): 267-287.

Skempton, A. W. 1951. The bearing capacity of clays, in Proc. Building Research Congress 1: 180-189.

Taiebat, H. A.; Carter, J. P. 2000. Numerical studies of the bearing capacity of the shallow foundations on cohesive soil subjected to combined loading, Geotechnique 50(4): 409-418. http://dx.doi.org/10.1680/geot.2000.50.4.409

Tani, K.; Craig, W. H. 1995. Bearing capacity of circular foundations on soft clay of strength increasing with depth, Soils and Foundations 35(4): 37-47. http://dx.doi.org/10.3208/sandf.35.4_21

Tjelta, T. I. 1995. Geotechnical experience from the installation of the Europipe jacket with bucket foundations, in Int. Proc $27^{\text {th }}$ Offshore Technology Conference, 1-4 May 1995, Houston, Texas, 897-908.

http://dx.doi.org/10.4043/7795-MS

Wang, Y.; Lu, X.; Wang, S.; Shi, Z. 2006. The response of bucket foundation under horizontal dynamic loading, Ocean Engineering 33(7): 964-973.

http://dx.doi.org/10.1016/j.oceaneng.2005.07.005

Woodward, R. J.; Lundgren, R.; Boitano, J. D. 1961. Pile loading tests in stiff clays, in Proc. of the Fifth International Conference on Soil Mechanics and Foundation Engineering 2: 177-184.

Yun, G.; Bransby, M. F. 2007. The undrained vertical bearing capacity of skirted foundations, Soils Found. 47(3): 493506. http://dx.doi.org/10.3208/sandf.47.493

Zhang, J. H.; Zhang, L. M.; Lu, X. B. 2007. Centrifuge modeling of suction bucket foundations for platforms under ice-sheet-induced cyclic lateral loadings, Ocean Engineering 34(8-9): 1069-1079. http://dx.doi.org/10.1016/j.oceaneng.2006.08.009

Zhang, S.; Zheng, Q.; Liu, X. 2004. Finite element analysis of suction penetration seepage field of bucket foundation platform with application to offshore oilfield development, Ocean Engineering 31(11-12): 1591-1599. http://dx.doi.org/10.1016/j.oceaneng.2004.03.001

\begin{abstract}
Amin BARARI is a Researcher at the Department of Civil Engineering at Aalborg University, Denmark. His publications have received more than 300 citations, including more than 110 refereed international journals according to Scopus (hindex: 11). He has published more than 100 refereed journal papers as well. These papers cover many aspects of research dealing with geotechnical engineering and nonlinear mechanics. His research is in soil improvement, landslides, unsaturated soils and offshore foundations, focusing mainly on the reinforced slopes, and drained and undrained behavior of offshore bucket foundations. He has also been working on soil liquefaction as well as nonlinear mechanics.
\end{abstract}

Lars Bo IBSEN is a Professor at the Department of Civil Engineering at Aalborg University, Denmark. His current research interests include offshore foundations, wind turbines and subsidence problems. 